\title{
Ecological and Functional Properties of Steppe Soils under Moderate Anthropogenic Impact
}

\author{
Clement T. Ngun ${ }^{*}$, Yekaterina V. Pleshakova1, Michael V. Reshetnikov ${ }^{2,3}$ \\ ${ }^{1}$ Department of Biochemistry and Biophysics, Faculty of Biological Sciences, Saratov State University Named after N.G. \\ Chernyshevsky, Saratov, Russia \\ ${ }^{2}$ Laboratory of Geoecology and Ecological Geochemistry, Saratov State University Named after N.G. Chernyshevsky, Saratov, Russia \\ ${ }^{3}$ LUKOIL-Engineering LLC, Kogalymnipineft Branch in Tyumen, Laboratory of Mineralogy and Geochemistry of Rocks, \\ Kogalym, Russia \\ Email: *clementngun@yahoo.com
}

How to cite this paper: Ngun, C.T., Pleshakova, Y.V. and Reshetnikov, M.V. (2020) Ecological and Functional Properties of Steppe Soils under Moderate Anthropogenic Impact. Journal of Agricultural Chemistry and Environment, 9, 206-222.

https://doi.org/10.4236/jacen.2020.94017

Received: July 23, 2020

Accepted: September 7, 2020

Published: September 10, 2020

Copyright (c) 2020 by author(s) and Scientific Research Publishing Inc. This work is licensed under the Creative Commons Attribution International License (CC BY 4.0).

http://creativecommons.org/licenses/by/4.0/

(c) (i) Open Access

\begin{abstract}
Steppe soils of a small industrialized city with moderate anthropogenic impact for example Krasny Kut, Saratov region were analysed to ascertain their ecological and functional state. In the course of this work, the concentration of heavy metals ( $\mathrm{Zn}, \mathrm{Cu}, \mathrm{Pb}, \mathrm{Ni}, \mathrm{Cr}$ and $\mathrm{Cd}$ ) was determined in the soil samples, including the hazard coefficient $(K o)$ and the total contamination coefficient $\left(Z_{c}\right)$. Magnetic susceptibility, magnetic coefficient $\left(K_{m a g}\right)$, thermomagnetic effect ( $d k$ ) of the soil samples were analysed together with the activity of soil enzymes (dehydrogenases, catalases, peroxidases and invertases). Using ecological and geochemical analytical methods, a widespread excess of maximum permissible concentration (MPC) of mobile forms $\mathrm{Ni}, \mathrm{Pb}, \mathrm{Cu}$ and $\mathrm{Zn}$ was recorded in the soil samples of Krasny Kut, and a single excess of MPC was observed for $\mathrm{Cr}$ and $\mathrm{Cd}$. According to $Z_{c}$ indicator values, 4 samples were classified as soils with moderately dangerous levels of contamination and 2 samples with dangerous levels of contamination. Using petromagnetic analysis, a few samples were observed to contain a moderate amount of introduced technogenic magnetic particles and one sample with a hazardous amount of introduced technogenic magnetic particles. Medium, high and very high levels of dehydrogenase, catalase, peroxidase and invertase activities were recorded in the soil samples, indicating the absence of ecotoxicants inhibiting the enzymes. The observed peculiarities in the ecological and functional state of soils, representative of the steppe zone of the Eastern part of the European territory of Russia will be required for monitoring, reducing and forecasting the anthropogenic burden on soil ecosystems.
\end{abstract}

\section{Keywords}

Heavy Metals, Hydrocarbons, Soil, Dehydrogenase, Catalase, Peroxidase and 


\section{Introduction}

Due to an exponential growth in industrial production and an increase in anthropogenic impact on the environment, researches on the assessment of soil contamination with dangerous xenobiotics, primarily heavy metals (HMs) and hydrocarbons (HCs), which have mutagenic, teratogenic and carcinogenic properties and pose an immediate threat to human health, have become particularly relevant in recent decades [1] [2] [3] [4]. Problems of soil contamination with HMs and HCs in large cities are given much attention both in Russia [5] [6] and in other countries [4] [7]. For a comprehensive assessment of the integral impact of HMs and HCs on abiotic and biotic components of urban soils, comprehensive studies of ecological, functional, biological, geochemical and physical-chemical properties of soils, including magnetic properties have to be conducted [8] [9].

Many researchers have shown that magnetic susceptibility values of urban soils increase with an increase in their technogenic magnetite content, which is capable of absorbing different HMs [10] [11] [12]. Therefore, to identify sources of HM contamination of urban soils, an assessment of the magnetic susceptibility of soils is used while an assessment of thermomagnetic effect is used to search for hydrocarbon contamination [13] [14].

Under the influence of increased concentrations of HMs and HCs, many researchers have established changes in soil biological activities: reduction in the number of certain groups of soil microorganisms [15] [16] [17] [18] and an inhibition of soil enzyme activities (dehydrogenases, catalases, ureases, amylases, invertases, etc.) [19] [20] [21]. Based on these facts, the number of microorganisms of certain ecological and physiological groups and the activity of soil enzymes are widely used as indicators in soil-ecological monitoring of urban soils [22] [23] [24]. At the same time, there has been very little research conducted on the biological, ecological, geochemical and magnetic properties of soils in small industrialized cities.

The authors show that the size of a locality (the number of inhabitants and the associated amount of waste introduced into the landscape), as well as the profiles of enterprises operating in the locality, determine the technogenic migration of elements into the soils. Also, the degree of soil degradation under the influence of xenobiotics and methods of rehabilitation is largely dependent on the properties of the soil itself and the climatic features of the area. For Saratov region, located in the steppe zone of the Eastern part of the European territory of Russia, steppe soils are predominant, which are characterized by a certain vulnerability to pollutants due to the arid climate and excessive accumulation of carbonates, chlorides, and sulfates in the soil profile or in the subsurface layers [25]. 
The purpose of this research is to assess the ecological and functional state of steppe soils with moderate anthropogenic impact using a small industrialized city-Krasny Kut in Saratov region as an example.

\section{Materials and Methods}

The objects of the study were chestnut saline and chestnut carbonate soils sampled from a moderately industrialized city Krasny Kut, Saratov region, located in the southern part of the Saratov Volga region in the zone of dry tipchak-kovyl steppes on a low-level plain. These soils were formed under conditions of unstable and insufficient moisture precipitation. The mechanical composition of the soil is clay and heavy loam. The selected soils are classified by us as natural surface-transformed soils (urbo-soils). Diagnostics of the main types of urban soils was carried out according to the principles of profile-genetic systematics of soils and soil-like bodies, developed by M. N. Stroganova et al. $(1992,1997)$ [26] [27], natural and conditionally undisturbed horizons were determined in accordance with the "Classification and diagnostics of soils in Russia" (1977) [25] taking into account regional features [28].

\subsection{Study Area Description and Sampling}

The City Krasny Kut with an area of $8 \mathrm{~km}^{2}$ and a population of 14,800 people is specialized in and represented by enterprises of regional significance in machine-building, metalworking, electricity and food industries. Relatively unfavorable environmental conditions were found in areas of garage and industrial development, in areas of municipal solid waste landfills and filtration fields that have a negative impact on atmospheric air, soil and vegetation cover, surface and underground water. In the course of this research on the territory of Krasny Kut, 24 soil samples were studied (Figure 1).

Sampling and preparation of samples for analysis were carried out in accordance with GOST 17.4.4.02-84 [29]. Soil sampling took into account the wind rose, the features of the microrelief, the layout of buildings and communications. According to GOST, the upper part of the soil horizon "A" was tested to a depth of $5-10 \mathrm{~cm}$. The size of the test sites ranged from $2-3$ to $10 \mathrm{~m}^{2}$. Samples were taken using the "envelope" method. The weight of the combined sample was from 0.5 to $1.0 \mathrm{~kg}$.

\subsection{Determination of Heavy Metal Concentrations}

Concentrations of HMs in the soil samples were determined by atomic absorption spectrometry with flame atomization on a "KVANT-2AT" spectrophotometer. Mobile acid-soluble forms of $\mathrm{HMs}(\mathrm{Cu}, \mathrm{Zn}, \mathrm{Ni}, \mathrm{Cd}, \mathrm{Pb})$ were determined in extracts of $1 \mathrm{M} \mathrm{HNO}_{3}$ [30]. To identify environmentally dangerous levels of $\mathrm{HM}$ concentrations in the soil, the actual concentration of each HM was compared with its MPC, calculating the hazard coefficient (Ko) using the formula [30]:

$$
\mathrm{Ko}=\mathrm{Ci} / \mathrm{MPC}
$$




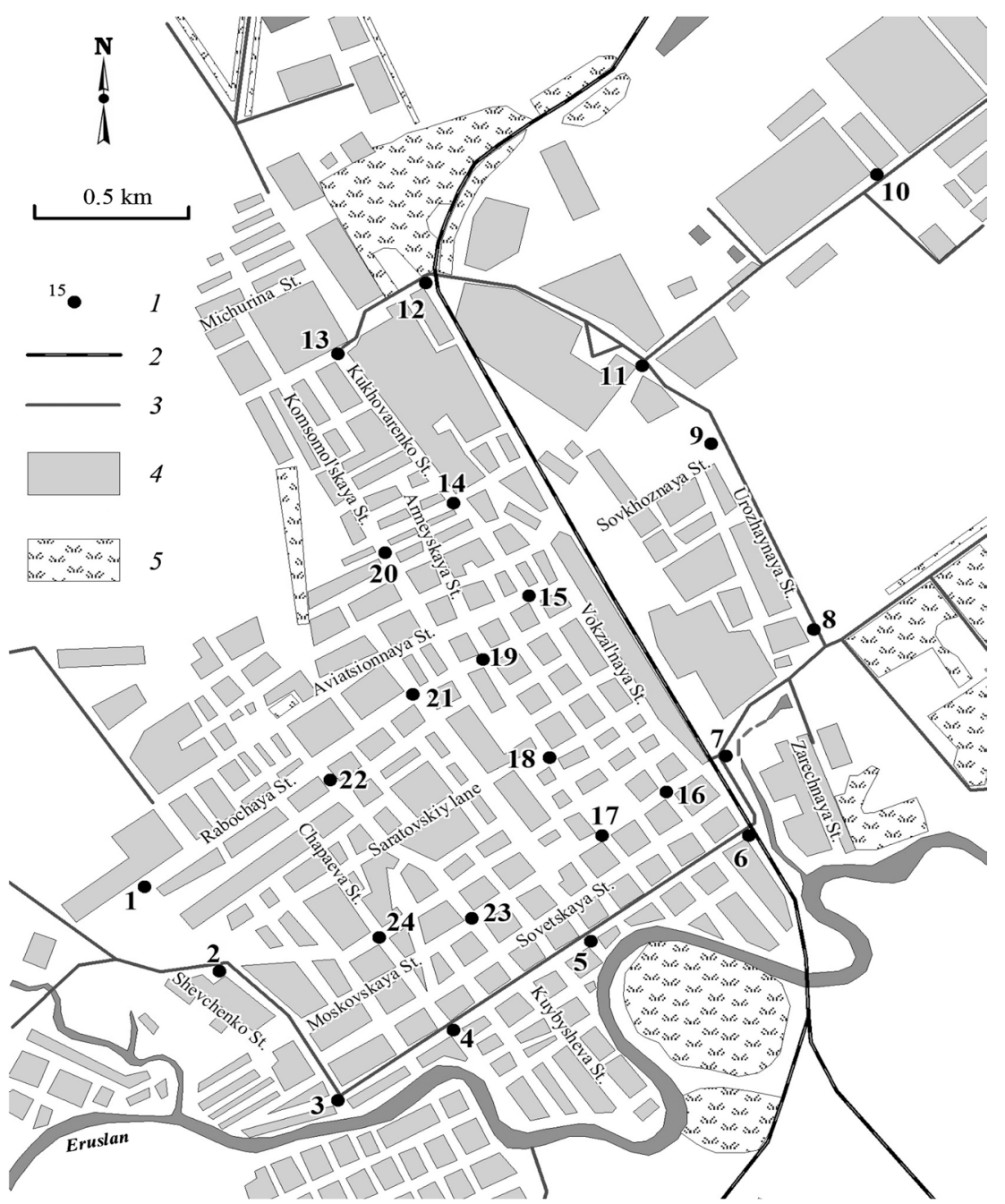

Figure 1. Map showing soil sample locations in the territory of the city Krasny Kut. 1-sampling site, 2-railway, 3-car road, 4-housing estate, 5-green area Note: ${ }^{\star}$ According to the laboratory of Geoecology, Saratov State University.

where $C i$ is the content of the HM form in the sample, $\mathrm{mg} \cdot \mathrm{kg}^{-1}$; MPC is the maximum permissible concentration of the $\mathrm{HM}, \mathrm{mg} \cdot \mathrm{kg}^{-1}$.

Mobile forms of HMs were used to assess the extent of soil geochemical transformation by determining the total rate of pollution $\left(Z_{c}\right)$ using the formula [30]:

$$
Z_{c}=\sum K o_{n}-(\mathrm{n}-1)
$$

where $n$ is the number of the identified elements; Ko-hazard coefficient of HM determined in the sample. When calculating $Z_{\mathcal{c}}$ we used an excess over the MPC (Ko) [31].

\subsection{Determination of Magnetic Susceptibility and Thermomagnetic Effect}

The specific magnetic susceptibility of the soil samples was measured in the laboratory using a serial KT-10 kappameter at a low frequency $(\mathrm{KLF}, 976 \mathrm{~Hz})$ and 
at a high frequency (KHF, $3904 \mathrm{~Hz})$. Magnetic susceptibility was measured ten times in each sample, the average value was calculated and expressed in $10^{-8}$ $\mathrm{m}^{3} \cdot \mathrm{kg}^{-1}$ [13]. To assess the extent to which technogenic magnetic particles were introduced into soils, we used the coefficient of magnetism $\left(K_{m a g}\right)$, which was calculated based on measurements of magnetic susceptibility using the formula [13]:

$$
K_{\text {mag }}=K_{i} / K_{\text {fon }}
$$

where $K_{i}$ is the average value of magnetic susceptibility in the soil, and $K_{\text {fon }}$ is the average value of magnetic susceptibility in the background area.

When evaluating thermomagnetic effect $(d k)$, the increase in magnetic susceptibility values of each samples after heating to $500^{\circ} \mathrm{C}$ in an oxidizing medium was determined using the formula [13]:

$$
d k=k_{t}-k
$$

where $k$ is the magnetic susceptibility, and $k_{t}$ is the magnetic susceptibility after heating.

\subsection{Determination of Soil Enzyme Activities}

The total activities of soil dehydrogenases $(\mathrm{AD})$, catalases $(\mathrm{AC})$, peroxidases (AP) and invertases (AI) were determined according to methods in soil enzymology. The activity of dehydrogenases was determined photometrically on the iMARK microplate photometer through a reduction of the colorless substrate of 2,3,5-triphenyltetrazolium chloride, which after accepting hydrogen mobilized by dehydrogenases, turned into 2,3,5-triphenylformazane (2,3,5-TFF) with a red color. The amount of 2,3,5-TFF was calculated using a pre-constructed calibration curve [32]. Activity of dehydrogenases was expressed as mg TFF $10 \mathrm{~g}^{-1}$ of dry soil.day ${ }^{-1}$.

Activity of catalases (AC) was determined using a titrimetric method [33], based on the amount of undecomposed peroxide which was determined by permanganatometric titration and measuring the rate of decomposition of hydrogen peroxide when interacting with soil. $\mathrm{AC}$ was expressed in $\mathrm{mL} 0.1 \mathrm{~N} \mathrm{KMnO}_{4}$ $\mathrm{g}^{-1}$ of dry soil. $\mathrm{h}^{-1}$.

The activities of peroxidases (AP) and invertases (AI) were measured photometrically using a LEKI SS2107UV spectrophotometer. The activity of peroxidases was evaluated based on the ability of peroxidases to catalyze the oxidation of hydroquinone in the presence of oxygen peroxide to 1,4-benzoquinone with a yellow color [34]. The amount of 1,4-benzoquinone was calculated using a pre-constructed calibration curve. AP was expressed in $\mathrm{mg}$ of 1,4-benzoquinone $\mathrm{g}^{-1}$ of dry soil per $30 \mathrm{~min}$ at $30^{\circ} \mathrm{C}$.

The activity of invertases (AI) was determined by a method based on the ability of invertases to catalyze the splitting of sucrose into monosaccharides [21]. Reducing sugars in the filtrate were detected using a $0.2 \%$ alkaline solution of ferricyanide, their content was calculated on a standard scale made up of glucose. AI was expressed in $\mathrm{mg}$ of glucose $\cdot \mathrm{g}^{-1}$ of dry soil.day ${ }^{-1}$. All data on the ac- 
tivity of enzymes were recalculated on air-dried samples.

All the analyses were performed in triplicates. For all the data obtained, average values were calculated, which were compared using statistical indicators of standard deviation and the slightest significant difference. Statistical processing of experimental data was performed using Microsoft Excel 2010 application software package (for Windows). Differences were considered reliable when the probability of error $\mathrm{p}=0.05$ (95\% confidence interval). The relationships between the ecological-geochemical, magnetic and biological properties of soils were evaluated by correlation analysis using the Pearson coefficient.

\section{Results and Discussion}

In other to obtain information on the functional and ecological state of the steppe soils of Krasny Kut, we used a comprehensive scientific and methodological approach based on the study of ecological, geochemical, magnetic and biological properties of soils. The results of the ecological-geochemical and petromagnetic analysis of soils in Krasny Kut are presented in Table 1.

Table 1. Results of ecological-geochemical and petromagnetic analysis of soils of Krasny Kut.

\begin{tabular}{|c|c|c|c|c|c|c|c|c|c|c|c|c|c|c|c|}
\hline \multirow{2}{*}{$\begin{array}{c}\text { Sample } \\
\text { No. }\end{array}$} & \multicolumn{6}{|c|}{ HM Concentration, $\mathrm{mg} \cdot \mathrm{kg}^{-1}$ of soil } & \multicolumn{6}{|c|}{ Ko } & \multirow{2}{*}{$Z_{c}$} & \multirow{2}{*}{$K_{m a g}$} & \multirow{2}{*}{$\mathrm{dk}$} \\
\hline & $\mathrm{Cr}$ & $\mathrm{Ni}$ & $\mathrm{Pb}$ & $\mathrm{Zn}$ & $\mathrm{Cd}$ & $\mathrm{Cu}$ & $\mathrm{Cr}$ & $\mathrm{Ni}$ & $\mathrm{Pb}$ & $\mathrm{Zn}$ & $\mathrm{Cd}$ & $\mathrm{Cu}$ & & & \\
\hline 1 & 2.23 & 6.58 & 8.60 & 11.26 & 0.08 & 6.02 & 0.37 & 1.65 & 1.43 & 0.49 & 0.08 & 2.01 & 1.03 & 0.35 & 1.11 \\
\hline 2 & 2.34 & 9.96 & 8.92 & 15.78 & 0.23 & 6.58 & 0.39 & 2.49 & 1.49 & 0.69 & 0.23 & 2.19 & 2.47 & 0.25 & 1.98 \\
\hline 3 & 1.75 & 6.78 & 16.90 & 47.83 & 0.13 & 6.49 & 0.29 & 1.70 & 2.82 & 2.08 & 0.13 & 2.16 & 4.17 & 0.63 & 1.62 \\
\hline 4 & 2.16 & 5.97 & 17.17 & 94.26 & 0.41 & 8.60 & 0.36 & 1.49 & 2.86 & 4.10 & 0.41 & 2.87 & 7.09 & 1.44 & 2.23 \\
\hline 5 & 2.88 & 8.92 & 27.69 & 90.75 & 0.24 & 13.78 & 0.48 & 2.23 & 4.62 & 3.95 & 0.24 & 4.59 & 11.10 & 1.78 & 1.72 \\
\hline 6 & 2.36 & 7.97 & 61.01 & 62.53 & 0.17 & 325.39 & 0.39 & 1.99 & 10.17 & 2.72 & 0.17 & 108.46 & 118.91 & 4.93 & 2.43 \\
\hline 7 & 2.37 & 7.28 & 31.94 & 61.48 & 0.19 & 10.53 & 0.40 & 1.82 & 5.32 & 2.67 & 0.19 & 3.51 & 8.92 & 1.21 & 3.31 \\
\hline 8 & 1.94 & 5.90 & 50.49 & 48.37 & 0.27 & 9.38 & 0.32 & 1.48 & 8.41 & 2.10 & 0.27 & 3.13 & 10.71 & 0.84 & 2.90 \\
\hline 9 & 4.50 & 8.99 & 13.30 & 19.82 & 0.21 & 9.40 & 0.75 & 2.25 & 2.22 & 0.86 & 0.21 & 3.13 & 4.42 & 0.55 & 1.67 \\
\hline 10 & 2.92 & 9.28 & 52.15 & 51.25 & 0.18 & 10.59 & 0.49 & 2.32 & 8.69 & 2.23 & 0.18 & 3.53 & 12.44 & 0.94 & 1.74 \\
\hline 11 & 2.98 & 12.44 & 16.97 & 29.97 & 0.13 & 8.17 & 0.50 & 3.11 & 2.83 & 1.30 & 0.13 & 2.72 & 5.59 & 1.47 & 1.02 \\
\hline 12 & 3.30 & 8.24 & 43.01 & 196.50 & 0.30 & 54.36 & 0.55 & 2.06 & 7.17 & 8.54 & 0.30 & 18.12 & 31.74 & 1.63 & 2.55 \\
\hline 13 & 5.63 & 13.77 & 33.59 & 214.66 & 0.77 & 75.55 & 0.94 & 3.44 & 5.60 & 9.33 & 0.77 & 25.18 & 40.27 & 0.88 & 1.82 \\
\hline 14 & 2.79 & 9.16 & 61.89 & 176.80 & 0.27 & 34.77 & 0.46 & 2.29 & 10.32 & 7.69 & 0.27 & 11.59 & 27.62 & 0.92 & 1.91 \\
\hline 15 & 2.63 & 8.62 & 31.70 & 59.59 & 0.16 & 13.67 & 0.44 & 2.15 & 5.28 & 2.59 & 0.16 & 4.56 & 10.18 & 0.54 & 1.94 \\
\hline 16 & 2.16 & 8.67 & 17.54 & 50.11 & 0.20 & 8.53 & 0.36 & 2.17 & 2.92 & 2.18 & 0.20 & 2.84 & 5.67 & 0.59 & 1.14 \\
\hline 17 & 2.87 & 8.24 & 33.26 & 79.71 & 0.23 & 13.01 & 0.48 & 2.06 & 5.54 & 3.47 & 0.23 & 4.34 & 11.12 & 0.93 & 1.66 \\
\hline 18 & 2.55 & 8.36 & 31.54 & 227.83 & 0.96 & 10.38 & 0.42 & 2.09 & 5.26 & 9.91 & 0.96 & 3.46 & 17.09 & 0.68 & 1.77 \\
\hline 19 & 3.09 & 9.06 & 28.58 & 182.32 & 0.21 & 10.50 & 0.51 & 2.27 & 4.76 & 7.93 & 0.21 & 3.50 & 14.18 & 0.99 & 3.60 \\
\hline 20 & 2.30 & 9.98 & 14.48 & 26.56 & 0.24 & 13.36 & 0.38 & 2.49 & 2.41 & 1.15 & 0.24 & 4.45 & 6.14 & 0.77 & 1.19 \\
\hline 23 & 33.73 & 28.07 & 15.69 & 107.44 & 2.19 & 13.21 & 5.63 & 7.02 & 2.61 & 4.67 & 2.19 & 4.40 & 21.53 & 0.34 & 3.42 \\
\hline 24 & 1.97 & 6.29 & 9.32 & 58.51 & 0.08 & 6.89 & 0.33 & 1.57 & 1.55 & 2.54 & 0.08 & 2.30 & 3.38 & 0.29 & 1.33 \\
\hline
\end{tabular}


Mobile forms of $\mathrm{Cr}$ were detected in all samples, and the average content in the samples was $3.97 \mathrm{mg} \cdot \mathrm{kg}^{-1}$ of soil, which was lower than the MPC $\left(6.0 \mathrm{mg} \cdot \mathrm{kg}^{-1}\right.$ of soil) [35]. The average value of the hazard coefficient $\mathrm{Cr}$ was 0.66 . Excess over the MPC was recorded in only one sample No. 23 (5.63). Mobile forms of Ni were recorded in all samples in concentrations from 4.56 to $28.07 \mathrm{mg} \cdot \mathrm{kg}^{-1}$ of soil exceeding the MPC (4.0 mg. $\mathrm{kg}^{-1}$ of soil) [35]. Ni hazard ratio ranged from 1.14 to 7.02. The maximum excess over the MPC was observed in sample No. 23 (7.02).

$\mathrm{Pb}$ in mobile form was detected in all samples in concentrations ranging from 8.60 to $61.89 \mathrm{mg} \cdot \mathrm{kg}^{-1}$ of soil, which exceeded the MPC (6.0 $\mathrm{mg} \cdot \mathrm{kg}^{-1}$ of soil) [35]. The hazard ratio of $\mathrm{Pb}$ varied in the range of 1.43 to 10.32. Excess over the MPC was detected in all samples, with the maximum excess in sample No. 14 (10.32). Mobile forms of $\mathrm{Zn}$ were recorded in all samples, ranging from 11.26 to 227.83 $\mathrm{mg} \cdot \mathrm{kg}^{-1}$ of soil and in most samples exceeding the MPC $\left(23.0 \mathrm{mg} \cdot \mathrm{kg}^{-1}\right.$ of soil) [36]. The hazard ratio for $\mathrm{Zn}$ was between 0.49 and 9.91. Excess over the MPC was detected in 20 samples with the highest maximum excess detected in sample No. 18 (9.91). Mobile forms of Cd were detected in all samples, its average content in the samples was $0.34 \mathrm{mg} \cdot \mathrm{kg}^{-1}$ of soil, which was lower than the MPC $(1.0$ $\mathrm{mg} \cdot \mathrm{kg}^{-1}$ of soil) [35]. The average value of the hazard ratio of $\mathrm{Cd}$ was equal to 0.34. Excess over the MPC was observed only in sample No. 23 (2.19 MPC). Cu in mobile form was detected in all samples at concentrations ranging from 5.46 to $325.39 \mathrm{mg} \cdot \mathrm{kg}^{-1}$ of soil exceeding the MPC $\left(3.0 \mathrm{mg} \cdot \mathrm{kg}^{-1}\right.$ of soil) [37]. The hazard ratio of $\mathrm{Cu}$ varied in the range of 1.82 to 108.46. Excess over the MPC was observed in all samples, the maximum excess was found in sample No. 6 (108.46 MPC).

Thus, based on the obtained data, a geochemical series of mobile forms of HMs $\mathrm{n}$ the soils of Krasny Kut was established: $\mathrm{Zn}>\mathrm{Cu}>\mathrm{Pb}>\mathrm{Ni}>\mathrm{Cr}>\mathrm{Cd}$. Analysis of the results enabled us to divide the studied elements into two groups: the first group includes $\mathrm{Pb}, \mathrm{Ni}, \mathrm{Cu}$ and $\mathrm{Zn}$, whose concentrations exceeded the MPC in most samples, the second group includes $\mathrm{Cd}$ and $\mathrm{Cr}$, whose concentrations exceeded the MPC in a single sample. The results obtained are consistent with data obtained by V. A. Alekseenko et al., which showed that in all cities, regardless of their size, $\mathrm{Zn}$ and $\mathrm{Pb}$ are the primary soil pollutants.

The total coefficient of contamination in the studied area, as shown by our calculations, varied within the range from 1.03 to 118.91 units (Table 1). Thus 18 soil samples were assigned to the category of soils with an acceptable level of pollution ( $Z_{c}$ from 0 to 16 units), 4 soil samples were classified as hazardous with moderate pollution levels ( $Z_{c}$ from 16 to 32 units), and 2 samples were classified as samples with dangerous levels of pollution ( $Z_{c} 32$ to 128 units) [30].

Conducted correlation analysis (Table 2) revealed two distinct groups of paragenetic associations of elements in the studied territory of Krasny Kut. The first group included the following associations: chromium-nickel, chromium-cadmium and nickel-cadmium with significant high correlation coefficients $(r=0.86-0.93$; $p$ $=0.05)$; the second group included associations such as: lead-zinc, zinc-cadmium 
and lead-copper with significant but not high correlation coefficients $(r=0.4$ $0.52 ; \mathrm{p}=0.05)$. Based on the results of correlation analysis, it was found that in the soils of Krasny Kut, of mobile form compounds of HMs orm two paragenetic associations-chromium-nickel-cadmium and lead-zinc-copper. Presumably, these elements have a single mineralogical origin derived from the parent rocks, or a common source of man-made origin. Similar anthropogenic factors associated with the activities of small enterprises of regional significance and different types of industries affect the environmental state of Krasny Kut. Road and rail transport were also sources of pollution.

It is known that magnetic susceptibility is an indicator of the presence of magnetic minerals in soil, primarily group of iron minerals (magnetite, hematite, and others). It has been proven that an increase in magnetic susceptibility on the surface of urban soils is a sign of man-made impact and an accumulation of strong magnetic iron compounds in the soil is as a result of industrial activity [10] [11] [12]. The values of magnetic susceptibility of soils in Krasny Kut, measured at a low frequency and were in the range of $2.0 \times 10^{-7} \mathrm{~m}^{3} \cdot \mathrm{kg}^{-1}$ to $4.1 \times$ $10^{-6} \mathrm{~m}^{3} \cdot \mathrm{kg}^{-1}$. Areas with increased values of soil magnetic susceptibility were located in the South-Eastern part of Krasny Kut and this was recorded in one sample (No. 6).

In general, magnetic susceptibility in the city Krasny Kut was evenly distributed without forming continuous anomalous fields. Magnetic susceptibility measured at a high frequency had a similar distribution in the soil cover.

A scale for values of magnetic coefficient reflecting the level of iron content in the soil was proposed by M. V. Reshetnikov et al. [13] [38]: whereby $K_{\text {mag }}<1=$

Table 2. Correlation coefficients $(r)$ between the enzymatic, ecological, geochemical and magnetic properties of soils in Krasny Kut.

\begin{tabular}{|c|c|c|c|c|c|c|c|c|c|c|c|c|c|}
\hline Indices & $\mathrm{AD}$ & $\mathrm{AP}$ & AC & $\mathrm{AI}$ & $C_{\mathrm{cr}}$ & $C_{\mathrm{Ni}}$ & $C_{\mathrm{Pb}}$ & $C_{\mathrm{Zn}}$ & $C_{\mathrm{Cd}}$ & $C_{\mathrm{Cu}}$ & $Z_{c}$ & $K_{\operatorname{mag}}$ & $d k$ \\
\hline $\mathrm{AD}$ & 1 & -0.14 & $0.76^{*}$ & $0.41^{*}$ & -0.01 & -0.01 & $0.51^{\star}$ & $0.61^{*}$ & 0.12 & 0.05 & $0.47^{*}$ & 0.01 & $0.60^{*}$ \\
\hline $\mathrm{AP}$ & & 1 & -0.31 & 0.05 & -0.18 & -0.24 & -0.32 & -0.25 & -0.20 & -0.20 & -0.34 & -0.19 & $-0.45^{\star}$ \\
\hline $\mathrm{AC}$ & & & 1 & $0.44^{*}$ & 0.00 & -0.03 & $0.51^{\star}$ & $0.44^{*}$ & 0.11 & 0.15 & $0.43^{*}$ & 0.15 & $0.50^{*}$ \\
\hline AI & & & & 1 & 0.08 & 0.19 & 0.31 & 0.33 & 0.17 & 0.09 & 0.16 & -0.02 & -0.04 \\
\hline$C_{\mathrm{cr}}$ & & & & & 1 & $0.93^{*}$ & -0.15 & 0.13 & $0.91^{*}$ & -0.04 & 0.07 & -0.15 & $0.42^{*}$ \\
\hline$C_{\mathrm{Ni}}$ & & & & & & 1 & -0.15 & 0.17 & $0.86^{*}$ & -0.03 & 0.08 & -0.13 & 0.27 \\
\hline$C_{\mathrm{Pb}}$ & & & & & & & 1 & $0.41^{\star}$ & -0.06 & $0.52^{*}$ & $0.62^{*}$ & $0.55^{*}$ & 0.35 \\
\hline$C_{\mathrm{Zn}}$ & & & & & & & & 1 & $0.40^{*}$ & 0.10 & 0.28 & 0.08 & 0.36 \\
\hline$C_{\mathrm{Cd}}$ & & & & & & & & & 1 & -0.03 & 0.11 & -0.14 & $0.41^{*}$ \\
\hline$C_{\mathrm{Cu}}$ & & & & & & & & & & 1 & $0.98^{*}$ & $0.90^{*}$ & 0.15 \\
\hline$Z_{c}$ & & & & & & & & & & & 1 & $0.87^{*}$ & 0.26 \\
\hline$K_{\text {mag }}$ & & & & & & & & & & & & 1 & 0.19 \\
\hline$d k$ & & & & & & & & & & & & & 1 \\
\hline
\end{tabular}

Note: ${ }^{\star}$ Significant correlation, with $\mathrm{r}$ corresponding to the level of statistical significance at $\mathrm{p}=0.05$. Abbreviations: AD-dehydrogenase activity; APperoxidase activity; $\mathrm{AC}$-catalase activity; AI—invertase activity; $C$-metal concentration; $Z_{c}$-total contamination coefficient; $K_{m a g}-$ magnetic coefficient; $d k$ - thermomagnetic effect. 
acceptable levels of magnetic minerals of iron; $1<K_{\text {mag }}<1.5=$ moderate levels of magnetic minerals of iron; $1.5<K_{\text {mag }}<3=$ dangerous levels of magnetic minerals of iron; $K_{\text {mag }}>3$ = extremely dangerous levels of magnetic minerals of iron.

$K_{\text {mag }}$ values in the soils of Krasny Kut varied between 0.25 to 4.93 units (Table 1). In accordance with the scale proposed by M. V. Reshetnikov, it was concluded that in most of the territory of Krasny Kut, soils belonged to the category with an acceptable degree of introduced technogenic magnetic particles $\left(K_{m a g}<\right.$ 1).

Numerous research data have shown high correlations between the content of HMs and the value of magnetic susceptibility in various types of urban soils [10] [11] [12] [13] [39]. Increased magnetic coefficient in soil indicates an increase in technogenic (man-made) iron, which has the ability to absorb various HMs. In the studied territory of the city, there were several zones with soil samples classified as having moderate degrees of introduced technogenic magnetic particles (1 $\left.<K_{m a g}<1.5\right)$, these were samples No. 11 and No. 12 in the Northern part, No. 4 and No. 5 in the southern part, and No. 7 in the Eastern part of the studied territory. In the South-Eastern part of the territory, a single point anomaly (sample No. 6) was detected with a dangerous degree of introduced of technogenic magnetic particles $\left(K_{\text {mag }}=4.93\right)$.

It is known that soils in areas with oil and gas deposits, as well as soils contaminated with HCs, depending on specific conditions, have values of thermomagnetic effect varying from 3 to 30 units and more [13] [40] [41]. In the background soils, this indicator does not exceed 1.1 - 1.5 units. When hydrocarbon-oxidizing and sulfate-reducing bacteria interact with iron compounds in the soil, the formation of autigenic soil sulfides and iron carbonates occurs in high concentrations in zones where hydrocarbons are present, the content of which is recorded using thermomanometric analysis. In most soil samples on the territory of Krasny Kut, the values of thermomagnetic effect corresponded to levels for soils not contaminated with HCs $(d k \leq 1)$, in several samples $d k \geq 3$, which could indicate hydrocarbon contamination as shown in (Table 1).

Thus, results of ecological-geochemical and petromagnetic analyses indicated a moderate anthropogenic impact in conditions of a small industrialized city located in a steppe zone-Krasny Kut.

Soil microorganisms are characterized by dehydrogenase enzymes that catalyze the dehydrogenation of organic substances and serve as intermediate hydrogen carriers. These enzymes reflect the overall metabolic activity of the soil microflora, they do not accumulate in the soil, and they act in living microbial cells [42]. Many studies have shown that HCs and HMs entering the soil as a result of anthropogenesis reduce the activity of soil dehydrogenases [18] [20] [43]. The reasons for this decline include: direct inhibition of enzyme catalytic activity by the HMs when they react with substrate enzyme-substrate complex or the enzyme; direct inhibition of enzymes by aromatic hydrocarbons or oxidized products of certain hydrocarbons; or by blocking the interaction of the enzyme 
with its substrate when soil particles are enveloped by HCs. HMs partially or completely inactivate enzymes in soil microorganisms, which slows down their synthesis or contributes to blocking of respiratory chains of microorganisms thereby inhibiting their growth [44].

Taking into account the important role of soil dehydrogenases in various biological processes and their sensitivity to pollutants, we determined total dehydrogenase activities in the soil samples of Krasny Kut, which ranged between 2.6 to $9.6 \mathrm{mg}$ TFF $10 \mathrm{~g}^{-1}$ of dry soil.day ${ }^{-1}$ (Table 3). Minimum values were observed in samples 22 and 24 (2.6 mg TFF $10 \mathrm{~g}^{-1}$ of dry soil.day $\left.{ }^{-1}\right)$, which could indicate the presence of ecotoxicants in the soil sample. In (Table 2) significant direct correlations were observed between $\mathrm{AD}$ and $\mathrm{Zn}$ concentration $(\mathrm{r}=0.61 ; \mathrm{p}=$ 0.05), between $\mathrm{AD}$ and $\mathrm{Pb}$ concentration $(\mathrm{r}=0.51 ; \mathrm{p}=0.05)$ and a low significant direct correlation between $\mathrm{AD}$ and $Z_{c}(\mathrm{r}=0.47 ; \mathrm{p}=0.05)$. We assumed that,

Table 3. Indicators of enzyme activity in the soil of Krasny Kut.

\begin{tabular}{|c|c|c|c|c|}
\hline \multirow[b]{2}{*}{ Sample No. } & \multicolumn{4}{|c|}{ Enzyme Activities: } \\
\hline & $\begin{array}{l}\text { Dehydrogenase, mg TFF } 10 \\
\mathrm{~g}^{-1} \text { of dry soil } \cdot \text { day }^{-1}\end{array}$ & $\begin{array}{l}\text { Catalase, } \mathrm{mL} 0.1 \mathrm{~N} \\
\mathrm{KMnO}_{4} \mathrm{~g}^{-1} \text { of dry soil } \cdot \mathrm{h}^{-1}\end{array}$ & $\begin{array}{l}\text { Peroxidase, } \mathrm{mg} \text { of } 1,4 \text {-benzoquinone } \\
\mathrm{g}^{-1} \text { of dry soil per } 30 \mathrm{~min} \text { at } 30^{\circ} \mathrm{C}\end{array}$ & $\begin{array}{l}\text { Invertase, } \mathrm{mg} \text { of glucose } \cdot \mathrm{g}^{-1} \\
\text { of dry soil } \cdot \text { day }^{-1}\end{array}$ \\
\hline 1 & $3.5 \pm 2.12^{\star \star \star}$ & $7.35 \pm 1.34^{* * *}$ & $0.840 \pm 0.02^{\star * \star * \star}$ & $64.0 \pm 2.66^{\star * * *}$ \\
\hline 2 & $4.5 \pm 0.85^{\star * *}$ & $7.50 \pm 1.27^{\star * *}$ & $0.300 \pm 0.06^{* * *}$ & $53.6 \pm 0.91^{\star * * *}$ \\
\hline 3 & $3.8 \pm 0.21^{\star * \star}$ & $14.10 \pm 0.4^{* * * *}$ & $0.360 \pm 0.01^{\star * *}$ & $47.2 \pm 0.11^{\star \star \star}$ \\
\hline 4 & $7.0 \pm 0.71^{\star * *}$ & $33.35 \pm 1.91^{\star * * *}$ & $0.380 \pm 0.02^{\star \star \star}$ & $38.4 \pm 4.67^{\star \star \star}$ \\
\hline 5 & $4.1 \pm 0.21^{\star * *}$ & $19.45 \pm 1.06^{* * * *}$ & $0.365 \pm 0.03^{* * *}$ & $39.2 \pm 0.19^{* * *}$ \\
\hline 6 & $5.0 \pm 0.35^{\star * *}$ & $20.95 \pm 1.34^{\star * * *}$ & $0.275 \pm 0.03^{\star \star *}$ & $44.8 \pm 2.94^{* * *}$ \\
\hline 7 & $6.8 \pm 0.49^{\star * *}$ & $27.35 \pm 1.56^{* * * *}$ & $0.260 \pm 0.003^{* * *}$ & $33.6 \pm 2.55^{\star * *}$ \\
\hline 8 & $5.4 \pm 0.71^{\star * *}$ & $18.65 \pm 0.64^{* * * *}$ & $0.340 \pm 0.01^{* * *}$ & $25.6 \pm 2.04^{* * *}$ \\
\hline 9 & $4.1 \pm 0.21^{\star * *}$ & $11.85 \pm 0.49^{\star * * *}$ & $0.395 \pm 0.01^{\star * *}$ & $33.6 \pm 0.11^{\star * *}$ \\
\hline 10 & $6.0 \pm 0.49^{* * *}$ & $17.95 \pm 0.92^{\star * * *}$ & $0.370 \pm 0.01^{\star * \star}$ & $46.4 \pm 2.66^{* * *}$ \\
\hline 11 & $3.8 \pm 0.99^{\star * *}$ & $16.80 \pm 0.99^{\star * * *}$ & $0.350 \pm 0.04^{\star * \star}$ & $42.4 \pm 2.04^{\star \star \star}$ \\
\hline 12 & $6.0 \pm 1.98^{\star * *}$ & $10.40 \pm 2.26^{\star * * *}$ & $0.240 \pm 0.01^{\star * \star}$ & $32.8 \pm 0.91^{\star * *}$ \\
\hline 13 & $5.6 \pm 0^{* * *}$ & $19.10 \pm 0.35^{\star * * *}$ & $0.425 \pm 0.04^{* * * *}$ & $64.0 \pm 3.68^{* * * *}$ \\
\hline 14 & $7.8 \pm 0.92^{* * *}$ & $35.80 \pm 0.28^{* * * *}$ & $0.250 \pm 0.01^{* * *}$ & $108.0 \pm 4.53^{* * * *}$ \\
\hline 15 & $3.6 \pm 0.14^{* * *}$ & $9.30 \pm 0.57^{\star * *}$ & $0.305 \pm 0.03^{* * *}$ & $38.4 \pm 1.13^{\star * *}$ \\
\hline 16 & $4.8 \pm 1.13^{\star * *}$ & $12.05 \pm 1.06^{* * * *}$ & $0.520 \pm 0.04^{\star * * \star}$ & $40.8 \pm 0.17^{\star * *}$ \\
\hline 17 & $7.0 \pm 0.14^{* * *}$ & $13.95 \pm 3.18^{* * * *}$ & $0.830 \pm 0.04^{* * * * *}$ & $44.0 \pm 1.02^{\star * *}$ \\
\hline 18 & $6.0 \pm 0.21^{\star * \star}$ & $17.15 \pm 1.20^{* \star * *}$ & $0.380 \pm 0.004^{\star * *}$ & $52.8 \pm 0.34^{* * * *}$ \\
\hline 19 & $9.6 \pm 1.06^{* * *}$ & $28.60 \pm 0.71^{* * * *}$ & $0.375 \pm 0.01^{* * *}$ & $48.8 \pm 1.19^{* * *}$ \\
\hline 20 & $3.6 \pm 0.71^{\star * *}$ & $12.00 \pm 7.64^{* * * *}$ & $0.525 \pm 0.03^{* * * *}$ & $68.0 \pm 5.66^{* * * *}$ \\
\hline 21 & $4.1 \pm 0.07^{* * *}$ & $18.70 \pm 1.98^{\star * * *}$ & $0.555 \pm 0.07^{* * * *}$ & $36.8 \pm 1.64^{* * *}$ \\
\hline 22 & $2.6 \pm 0.35^{\star \star}$ & $6.50 \pm 1.70^{\star * \star}$ & $0.270 \pm 0.04^{\star * *}$ & $1.6 \pm 0.6^{*}$ \\
\hline 23 & $4.8 \pm 0.42^{\star * *}$ & $16.50 \pm 1.84^{* * * *}$ & $0.280 \pm 0.01^{* * *}$ & $48.8 \pm 1.98^{* * *}$ \\
\hline 24 & $2.6 \pm 0.28^{\star *}$ & $6.40 \pm 1.27^{\star * *}$ & $0.540 \pm 0.28^{\star * * *}$ & $4.0 \pm 0.11^{\star}$ \\
\hline
\end{tabular}

Note: According to a scale by D. G. Zvyagintsev [49] on the degree of enzyme enrichment: ${ }^{*}$-very poor; ${ }^{* *}$-poor; ${ }^{* * *}$-average; ${ }^{* * *}$-rich; ${ }^{* * * * *}$-very rich. The standard deviation was calculated with a probability of $95 \%(n=3)$. 
despite an increase in HM concentration in the soil, there was no negative effect on soil dehydrogenase activity. A significant direct correlation was also observed between $\mathrm{AD}$ and $d k(\mathrm{r}=0.60 ; \mathrm{p}=0.05)$. This relationship most likely pointed to recent hydrocarbon contamination in the sampled area.

From the class of oxidoreductases are catalases which are not less important soil enzymes which catalyze the decomposition of various peroxides and play an important role in soil oxygen balance [23]. Soil catalase activity is considered an indicator of aerobic microbial activity due to the fact that it reflects both the number of aerobic microorganisms and soil fertility. It is known that catalases, as well as dehydrogenases, can be inhibited by HMs and HCs [17] [21] [45]. AC in most soil samples of Krasny Kut varied between 10.40 to $35.80 \mathrm{~mL} 0.1 \mathrm{~N}$ $\mathrm{KMnO}_{4} \mathrm{~g}^{-1}$ of dry soil. $\mathrm{h}^{-1}$, indicating high activity (Table 3). Average levels of catalase activities were observed in samples 1, 2, 15, 22 and 24, in which AC was below $10 \mathrm{~mL} 0.1 \mathrm{~N} \mathrm{KMnO}_{4} \mathrm{~g}^{-1}$ of dry soil.h ${ }^{-1}$. Samples 1, 2, 22 and 24 were obtained from the same area as shown in Figure 1, while samples 22 and 24 were also characterized by lower AD values compared to other samples. The results obtained indirectly indicate adverse factors affecting soil oxidoreductases (dehydrogenases and catalases) in this area of the city. Maximum values of catalase activity were observed in soil samples No. 4 and No. 14 (33.35 and $35.80 \mathrm{~mL} 0.1 \mathrm{~N}$ $\mathrm{KMnO}_{4} \mathrm{~g}^{-1}$ of dry soil $\cdot \mathrm{h}^{-1}$ ). The conducted correlation analysis in Table 2 showed a strong positive correlation between $\mathrm{AC}$ and $\mathrm{AD}$ in the soil samples $(\mathrm{r}=$ $0.76 ; \mathrm{p}=0.05)$ and as it was in the case of dehydrogenases, there was a direct correlation between $\mathrm{AC}$ and $\mathrm{Pb}(\mathrm{r}=0.51 ; \mathrm{p}=0.05), \mathrm{Zn}(\mathrm{r}=0.44 ; \mathrm{p}=0.05)$, the contamination coefficient $Z_{c}(r=0.43 ; p=0.05)$ and the thermomagnetic effect $\mathrm{dk}(\mathrm{r}=0.50 ; \mathrm{p}=0.05)$.

In contrast to activities of dehydrogenases and catalases, soil peroxidases are predominantly of plant origin. These are inducible enzymes that oxidize organic compounds in soils (phenols, amines, some heterocyclic compounds), including components of oil pollution, due to oxygen, hydrogen peroxide and organic peroxides formed in soils as a result of microbial activities and the action of certain oxidases. Inhibition of peroxidases under the action of HMs and HCs has been reported in several researches [20] [45]. Low concentrations of oil initially stimulate the activity of these enzymes due to phenolic compounds while medium and high doses of oil have an inhibitory effect. Maximum values of AP were observed in two soil samples: No. 1 and No. 17 with values of 0.84 and $0.83 \mathrm{mg}$ 1.4-benzoquinone $\mathrm{g}^{-1}$ of dry soil per $30 \mathrm{~min}$ at $30^{\circ} \mathrm{C}$ respectively, which corresponded to very high levels of peroxidase activity (Table 3 ). In sample No. 1, a low $\mathrm{AC}$ value was also observed. It is possible that the simultaneous increase in $\mathrm{AP}$ and decrease in $\mathrm{AC}$ in this sample was due to hydrocarbon contamination, whose aromatic components as substrates induce peroxidase activity, and other substances (sulfur, hydrogen sulfide, mercaptans, phenol) are also known to inhibit catalases [46]. A number of samples were characterized by high levels of peroxidases (No. 13, 16, 20, 21 and 24). In the remaining samples, AP corres- 
ponded to the average level. There were no significant correlations between AP and the studied enzymatic, ecological, geochemical, and magnetic properties of the soil. This exception led to a low significant inverse correlation between AP and $\mathrm{dk}(\mathrm{r}=-0.45 ; \mathrm{p}=0.05)$.

Soil invertases ( $\beta$-fructofuranosidases) hydrolyze glycosyl compounds: sucrose, raffinose, gentianose and stachyose, catalyze fructotransferase reactions, and determine the level of soil fertility and biological activity [21]. These enzymes are highly sensitive to the effects of negative environmental factors, while at the same time, they are resistant to HM contamination [47]. This is due to the fact that invertases are hydrolytic enzymes, and HMs showing variable valences, significantly change the activity of redox enzymes. According to this indicator (activity of invertases), soil samples of Krasny Kut were characterized by an average and high level of activity. Samples No. 22 and No. 24 were exemptions, the activity of invertases (AI) was low, amounting to 1.6 and $4.0 \mathrm{mg}$ of glucose. $\mathrm{g}^{-1}$ of dry soil.day ${ }^{-1}$ respectively, which indicated very low levels (Table 3 ). Low values for $\mathrm{AD}$ and $\mathrm{AC}$ were also observed in these samples. Low values for $\mathrm{AI}$ indicated the possible action of soil pollutants. The maximum AI-108.0 mg of glucose. $\mathrm{g}^{-1}$ of dry soil.day ${ }^{-1}$ was detected in sample No. 14, which also registered the highest AC. These indicators of soil enzymatic activity in the studied area demonstrate the intensity of hydrolytic and oxidative processes in the soil. High AC and AI values may have been as a result of exposure to toxic chemicals leading to stress on the soil. This assumption was supported by results of HM contents. In sample №14, high concentrations of $\mathrm{Pb}\left(61.89 \mathrm{mg} \cdot \mathrm{kg}^{-1}\right)$ and $\mathrm{Zn}\left(176.80 \mathrm{mg} \cdot \mathrm{kg}^{-1}\right)$ were observed in comparison with other samples (Table 1$)$. Significantly low direct correlations between $\mathrm{AI}$ and $\mathrm{AD}(\mathrm{r}=0.41 ; \mathrm{p}=0.05)$, between $\mathrm{AI}$ and $\mathrm{AC}(\mathrm{r}=0.44 ; \mathrm{p}=$ $0.05)$, and between $\mathrm{AI}$ and $\mathrm{dk}(\mathrm{r}=0.42 ; \mathrm{p}=0.05)$ were observed (Table 2).

Thus, medium, high and very high levels of dehydrogenase, catalase, peroxidase and invertase activities were observed in the soil samples of Krasny Kut. According to the results obtained from the conducted enzymatic analysis, the soils of Krasny Kut can be considered to be in a state of ecological balance, although some exceptions exist.

In conditions of moderate technogenic impact of a small industrialized city in a steppe zone, positive correlations were established between the activities of dehydrogenases and catalases in the soil samples and the concentration of HMs: $\mathrm{Zn}$ and $\mathrm{Pb}$. It is known that HMs in low concentrations can have a stimulating effect on the activity of soil enzymes [48]. This led to an assumption that the data obtained for HMs and their corresponding concentrations did not have a negative effect on the studied soil enzymes. Significant direct correlations between the activity of enzymes (dehydrogenases, catalases, invertases) in soils and thermomagnetic effect could be an indication of recent hydrocarbon contamination.

\section{Conclusions}

As a result of the conducted analysis on the ecological and functional properties 
of soils in the small industrialized city of Krasny Kut, Saratov region, changes indicating a moderate anthropogenic impact on the soil were identified. In the studied soil samples, there were widespread excesses of MPC of mobile forms of the $\mathrm{HMs}: \mathrm{Ni}, \mathrm{Pb}, \mathrm{Cu}$ and $\mathrm{Zn}$, and single excesses of MPC were found for $\mathrm{Cr}$ and Cd. Calculations for $Z_{c}$ identified 4 soil samples which were classified as moderately hazardous and 2 samples classified as hazardous. Results of petromagnetic analyses revealed several anomalous zones with moderate degrees of introduced technogenic magnetic particles and a one point anomaly with a dangerous degree of introduced technogenic magnetic particles. High values of thermomagnetic effect detected in several samples and direct correlations between this indicator and the activity of enzymes (dehydrogenase, catalase, and invertase) could be an indication of hydrocarbon contamination.

An analysis of soil enzyme activities of the small industrialized city Krasny Kut did not reveal significant differences. Medium, high and very high levels of activity of dehydrogenases, catalases, peroxidases and invertases were observed, indicating the absence of ecotoxicants inhibiting soil enzymes.

Data obtained on the ecological and functional properties of soils in this steppe zone of the Eastern part of the European territory of Russia using a series of complex ecological, geochemical, petromagnetic and biological methods will be in demand for monitoring, reducing and predicting technogenic pollution in urbanized ecosystems.

\section{Acknowledgements}

The reported study was funded by the Russian Foundation for Basic Research-RFBR (Project number 19-35-90019).

\section{Conflicts of Interest}

The authors declare no conflicts of interest regarding the publication of this paper.

\section{References}

[1] Abbas, S.H., Ismail, I.M., Mostafa, T.M. and Sulaymon, A.H. (2014) Biosorption of Heavy Metals: A Review. Journal of Chemical Science and Technology, 3, 74-102.

[2] Gennadiev, A.N., Pikovskii, Y.I., Tsibart, A.S. and Smirnova, M.A. (2015) Hydrocarbons in Soils: Origin, Composition, and Behavior (Review). Eurasian Soil Science, 48, 1076-1089. https://doi.org/10.1134/S1064229315100026

[3] Skugoreva, S.G., Ashikhmina, T.Y., Fokina, A.I. and Lyalina, E.I. (2016) Chemical Bases of Toxic Action of Heavy Metals (Review). Teoreticheskaya i Prikladnaya Ekologiya [ Theoretical and Applied Ecology], 1, 4-13. (In Russian)

[4] Su, C., Jiang, L. and Zhang, W. (2014) A Review on Heavy Metal Contamination in the Soil Worldwide: Situation, Impact and Remediation Techniques. Environmental Skeptics and Critics, 3, 24-38.

[5] Alekseenko, V.A., Puzanov, A.V., Alekseenko, A.V. and Shvydkaya, N.V. (2017) About Some Ecological and Geochemical Features of the Soils of the Resorts of the Canary Islands. Vestnik Altaiskogo Gosudarstvennogo Agrarnogo Universiteta 
[Bulletin of Altai State Agrarian University], 1, 72-83. (In Russian)

[6] Ivanov, D.V. (2015) Heavy Metals in Soils of the Republic of Tatarstan (An Overview). Rossiiskii Zhurnal Prikladnoi Ekologii [Russian Journal of Applied Ecology], 4, 53-50. (In Russian)

[7] Beesley, L., Moreno-Jiménez, E., Jenn, P. and Lepp, N.W. (2020) Carbon and Metal(loid)s in Parkland and Road Verge Surface Soils in the City of Liverpool, UK. Agronomy, 10, 335-343. https://doi.org/10.3390/agronomy10030335

[8] Salah, E.A.M., Yassin, K.H. and Abd-Alsalaam, S. (2015) Level, Distribution and Pollution Assessment of Heavy Metals in Urban Community Garden Soils in Baghdad City, Iraq. International Journal of Scientific and Engineering Research, 6, 1646-1652.

[9] Kasimov, N.S., Bityukova, V.R., Malkhazova, S.M., Kosheleva, N.E., Nikiforova, E.M., Shartova, N.V., Vlasov, D.V., Timonin, S.A. and Krainov, V.N. (2014) Regiony i Goroda Rossii: Integral'naya Otsenka Ekologicheskogo Sostoyaniya [Regions and Cities of Russia: An Integrated Assessment of the Ecological State]. IP Filimonov M.V., Moscow. (In Russian)

[10] Vodyanitsky, Y.N. and Shoba, S.A. (2015) Magnetic Susceptibility as an Indicator of Heavy Metal Pollution in Urban Soils. Vestnik Moskovskogo Universiteta. Seriya 17: Pochvovedenie [Bulletin of Moscow University. Series 17: Soil Science], 1, 13-20. (In Russian)

[11] Bucko, M.S., Magiera, T., Johanson, B., Petrovský, E. and Pesonen, L.J. (2013) Distribution of Magnetic Particles in a Road Dust Snow Using Magnetic, Geochemical and Micromorphological Analyses. Geophysical Journal International, 195, 159-175.

[12] Zhu, Z., Sun, G., Bi, X., Li, Z. and Yu, G. (2013) Identification of Trace Metal Pollution in Urban Dust from Kindergartens Using Magnetic, Geochemical and Lead Isotopic Analyses. Atmospheric Environment, 77, 9-15. https://doi.org/10.1016/j.atmosenv.2013.04.053

[13] Reshetnikov, M.V. (2011) Magnitnaya Indikatsiya Pochv Gorodskikh Territorii (Na Primere g. Saratova) [Magnetic Indication of Soils of Urban Territories (On the Example of Saratov City)]. SGTU Publ., Saratov. (In Russian)

[14] Vodyanitskii, Y.N. and Savichev, A.T. (2017) Magnetite Contamination of Urban Soils in European Russia. Annals of Agrarian Science, 15, 155-162. https://doi.org/10.1016/j.aasci.2017.05.020

[15] Gennadiev, A.N. (2016) Oil and the Environment. Vestnik Moskovskogo Universiteta. Seriya 5: Geografiya [Bulletin of Moscow University. Series 5: Geography], 6, 30-39. (In Russian)

[16] Joynt, J., Bischoff, M., Turco, R., Konopka, A. and Nakatsu, C. H. (2006) Microbial Community Analysis of Soils Contaminated with Lead, Chromium and Petroleum Hydrocarbons. Microbial Ecology, 51, 209-219.

https://doi.org/10.1007/s00248-005-0205-0

[17] Hassan, W., Akmal, M., Muhammad, I., Younas, M., Zahaid, K.R. and Ali, F. (2013) Response of Soil Microbial Biomass and Enzymes Activity to Cadmium (Cd) Toxicity under Different Soil Textures and Incubation Times. Australian Journal of Crop Science, 7, 674-680.

[18] Murata, T., Kanao-Koshikawa, M. and Takamatsu, T. (2005) Effects of Pb, Cu, Sb, $\mathrm{Zn}$ and Ag Contamination on the Proliferation of Soil Bacterial Colonies, Soil Dehydrogenase Activity, and Phospholipid Fatty Acid Profiles of Soil Microbial Communities. Water, Air and Soil Pollution, 164, 103-118.

https://doi.org/10.1007/s11270-005-2254-x 
[19] Friedlová, M. (2010) The Influence of Heavy Metals on Soil Biological and Chemical Properties. Soil \& Water Resources, 5, 21-27. https://doi.org/10.17221/11/2009-SWR

[20] Ofoegbu, C.J., Akubugwo, E.I., Dike, C.C., Maduka, H.C.C., Ugwu, C.E. and Obasi, N.A. (2013) Effects of Heavy Metals on Soil Enzymatic Activities in the Ishiagu Mining Area of Ebonyi State-Nigeria. Journal of Environmental Science, Toxicology and Food Technology (IOSR-JESTFT), 5, 66-71. https://doi.org/10.9790/2402-0566671

[21] Shi, Z.J., Lu, Y., Xu, Z.G. and Fu, S.L. (2008) Enzyme Activities of Urban Soils Under Different Land Use in the Shenzhen City, China. Plant Soil and Environment, 54, 341-346. https://doi.org/10.17221/415-PSE

[22] Angelovičová, L., Bobul’ská, L. and Fazekašová, D. (2015). Toxicity of Heavy Metals to Soil Biological and Chemical Properties in Conditions of Environmentally Polluted Area Middle Spiš (Slovakia). Carpathian Journal of Earth and Environmental Sciences, 10, 193-201.

[23] Maila, M.P. and Cloete, T.E. (2005) The Use of Biological Activities to Monitor the Removal of Fuel Contaminants-Perspective for Monitoring Hydrocarbon Contamination: A Review. International Biodeterioration \& Biodegraddation, 55, 1-8. https://doi.org/10.1016/j.ibiod.2004.10.003

[24] Terekhova, V.A., Shitikov, V. K., Ivanova, A. E. and Kydralieva, K. A. (2017) Assessment of the Ecological Risk of Technogenic Soil Pollution on the Basis of the Statistical Distribution of the Occurrence of Micromycete Species. Russian Journal of Ecology, 48, 417-424. https://doi.org/10.1134/S1067413617050125

[25] Alekseenko, V.A., Rudsky, V.V. and Alekseenko, A.V. (2016) Influence of the Size of Settlements on Urban Soil Pollution. Geography and Natural Resources, 3, 26-36. (In Russian) https://doi.org/10.21782/GiPR0206-1619-2016-3(26-36)

[26] Egoro, V.V. (1977) Klassifikatsiya i Diagnostika Pochv SSSR [Classification and Soil Diagnostics of the USSR]. Kolos, Moscow, p. 221. (In Russian)

[27] Stroganova, M.N. and Agarkova, M.G. (1992) Urban Soils: Learning Experience and Systematics. Pochvovedenie [Soil Science], 7, 16-24. (In Russian)

[28] Stroganova, M.N., Myagkova, A.D. and Prokofieva, T.V. (1997) The Role of Soils in Urban Ecosystems. Pochvovedenie [Soil Science], 1, 96-101. (In Russian)

[29] Boldyrev, V.A. and Piskunov, V.V. (2006) Polevye Issledovaniya Morfologicheskikh Priznakov Pochv: Uchebnoe Posobie. 2-eizd. [Field Studies of Morphological Features of Soils: A Training Manual]. 2nd Edition, SGU Publ., Saratov. (In Russian)

[30] GOST 17.4.4.02-84 (2008) Protection of Nature. The Soils. Methods of Sampling and Sample Preparation for Chemical, Bacteriological, Helminthological Analysis: Interstate Standards. Standardinform, Moscow. (In Russian)

[31] Revich, B.A., Saet, Y.E. and Smirnova, R.S. (1990) Metodicheskie Rekomendatsii po Otsenke Stepeni Zagryazneniya Atmosfernogo Vozdukha Naselennykh Punktov Metallami po ikh Soderzhaniyu v Snezhnom Pokrove i Pochve. Utv. 15 maya 1990 g. No. 5174-90 [Guidelines for Assessing the Degree of Pollution of Atmospheric Air of Settlements with Metals According to Their Content in the Snow Cover and Soil. Approved May 15, No. 5174-90]. IMGRE, Moscow. (In Russian)

[32] Reshetnikov, M.V., Sokolov, E.S., Sheshnev, R.M. and Mamedov, R.M. (2017) The Concentration of Mobile Forms of Heavy Metals in the Soils of the Urban Settlement Stepnoe (Saratov Region). Ekologicheskaya Khimiya [Ecological Chemistry], 26, 141-145. (In Russian)

[33] Öhlinger, R. (1996) Dehydrogenase Activity with the Substrate TTC. In: Schinner, 
F., Ohlinger, R., Kandler, E. and Margesin, R., Eds., Methods in Soil Biology, Springer Verlag, Berlin, 241-243.

[34] Johnson, J.I. and Temple, K.L. (1964) Some Variables Affecting Measurement of Catalase Activity in Soil. Soil Science Society of American Journal, 28, 207-209. https://doi.org/10.2136/sssaj1964.03615995002800020024x

[35] Khaziev, F.K. (2005) Metody Pochvennoi Enzimologii [Soil Enzymology Methods]. Moscow, Science. (In Russian)

[36] GN 2.1.7.2041-06 (2006) Hygienic Standards. Maximum Allowable Concentration (MPC) of Chemicals in the Soil. Approved Chief Canitary Doctor of the Russian Federation. Moscow, Goskomsanepidnadzor of Russia. (In Russian)

[37] SanPiN 42-128-4433-87 (1999) Sanitary Standards for Permissible Concentrations of Chemicals in Soils. Approved Deputy Chief State Sanitary Doctor of the USSR, 10.30.88. No. 4433-87, Ed. from 02.07.99. (In Russian)

[38] Kuznetsov, A.V., Fesyun, A.P., Samokhvalov, S.G. and Makhonko, E.P. (1992) Metodicheskie Ukazaniya po Opredeleniyu Tyazhelykh Metallov v Pochvakh Sel'khozugodii i Produktsii Rastenievodstva [Guidelines for the Determination of Heavy Metals in Farmland Soils and Crop Production]. CINAO, Moscow. (In Russian)

[39] Reshetnikov, M.V. and Grebenyuk, L.V. (2012) The Use of the Method of Measuring Magnetic Susceptibility to Identify Areas of Technogenic Pollution of Soils of the City of Ulyanovsk. Izvestiya Saratovskogo Universiteta. Novaya Seriya. Seriya Khimiya. Biologiya. Ekologiya [News of the Saratov University. New Series. Series Chemistry. Biology. Ecology], 12, 103-110. (In Russian)

[40] Stroganova, M.N., Ivanov, A.V. and Gladysheva, M.A. (2012) Magnetic Susceptibility of Soils in Urban Areas (For Example, the City of Moscow). Doklady po Ekologicheskomu Pochvovedeniyu [Ecological Soil Reports], 16, 40-80. (In Russian)

[41] Sheshnev, A.S. and Reshetnikov, M.V. (2015) Petro- and Thermomagnetic Characteristics of Soils and Soils in the Area of the Oktyabrsky Waste Storage Site (Saratov). Izvestiya Saratovskogo Universiteta. Novaya seriya. Seriya Nauki o Zemle [News of the Saratov University. New Series. Earth Science Series], 15, 61-66. (In Russian) https://doi.org/10.18500/1819-7663-2015-15-2-61-66

[42] Pimenov, M.V., Manikin, A.G., Yampolskaya, O.B., Guzhikova, A.A. and Zhukov, A.N. (2007). Preliminary Results of Studies to Assess the Possibility of Quantitative Interpretation of Thermocappetometric Data. Izvestiya Saratovskogo Universiteta. Seriya Nauki o Zemle [News of the Saratov University. Earth Science Series], 7, 39-44. (In Russian)

[43] Das, S.K. and Varma, A. (2011) Role of Enzymes in Maintaining Soil Health. In: Shukla, G. and Varma A., Eds., Soil Enzymology, Soil Biology, Springer-Verlag, Berlin, 22, 25-42. https://doi.org/10.1007/978-3-642-14225-3_2

[44] Wyszkowska, J. and Wyszkowski, M. (2010) Activity of Soil Dehydrogenases, Urease, and Acid and Alkaline Phosphatases in Soil Polluted with Petroleum. Journal of Toxicology and Environmental Health, Part A, 73, 1202-1210. https://doi.org/10.1080/15287394.2010.492004

[45] Yeates, G.W., Orchard, V.A., Speir, T.W. Hunt, J.L. and Hermans, M.C.C. (1994) Impact of Pasture Contamination by Copper, Chromium, Arsenic timber Preservative on Soil Biological Activity. Biology and Fertility of Soils, 18, 200-208. https://doi.org/10.1007/BF00647667

[46] Achuba, F.I. and Okoh, P.N. (2014) Effect of Petroleum Products on Soil Catalase and Dehydrogenase Activities. Open Journal of Soil Science, 4, 399-406. 
https://doi.org/10.4236/ojss.2014.412040

[47] Margesin, R., Walder, G. and Schinner, F. (2000) The Impact of Hydrocarbon Remediation (Diesel Oil and Polycyclic Aromatic Hydrocarbons) on Enzyme Activities and Microbial Properties of Soil. Acta Biotechnologica, 20, 313-333.

https://doi.org/10.1002/abio.370200312

[48] Shuqing, L., Zhixin, Y., Xiaomin, W., Xiaogui, Z., Rutai, G. and Xia, L. (2007) Effects of $\mathrm{Cd}$ and $\mathrm{Pb}$ Pollution on Soil Enzymatic Activities and Soil Microbiota. Frontiers of Agriculture in China, 1, 85-89. https://doi.org/10.1007/s11703-007-0016-9

[49] Zvyagintsev, D.G. (1978) Soil Biological Activity and Scales for Evaluating Some of Its Indicators. Pochvovedenie [Soil Science], 6, 48-54. (In Russian) 